\title{
Pengaruh Komunikasi dan Motivasi Kerja Aparatur terhadap Kualitas Pelayanan sertifikat Tanah
}

\begin{abstract}
Sunarto
ABSTRACT

The subject matter of this research deals with the poor quality of land certification service and poor communication and working motivation of government employees at the Land Office of South Jakarta Municipality. Another finding found was that communication would produce greater impacts with support of conducive transparency / openness through systematically institutionalized organizations so that availability, sufficiency and sustainability of communicators, messages, media and disturbance to process can be ensured and realized. Effects of Communication and Working Motivation of Government Employees on the Quality of Land Certification Service at the Land Office of South Jakarta Municipality. Working motivation will increase if it goes along with the application of the principles of integrated interest handling, that is if the organization's interest is commensurate with the interest of management and personnel.
\end{abstract}

Kata kunci: komunikasi, motivasi kerja dan kualitas pelayanan.

\section{Pendahuluan}

Masalah yang menjadi bahasan pada penulisan ini adalah pelayanan di bidang sertifikasi pertanahan.

Penulis tertarik membahas pelayanan sertifikasi tanah, karena tanah merupakan karunia Tuhan Yang Maha Esa, memegang peranan sentral dalam tata kehidupan bermasyarakat, berbangsa dan bernegara.

Salah satu lembaga yang bertugas di bidang tersebut adalah Badan Pertanahan Nasional (BPN). Pelayanan sertifikasi tanah merupakan etalase BPN yang menggambarkan salah satu upaya pemerintah untuk memberikan perlidungan dan kepastian hukum, sehingga tanah dapat dipergunakan untuk sebesar-besarnya kemakmuran dan kesejahteraan rakyat. Diharapkan apabila kualitas pelayanan meningkat akan diperoleh adanya penyediaan informasi dan tertib administrasi pertanahan serta jaminan kepastian hukum hak atas tanah, sehingga dapat mendorong pemanfaatan tanah untuk sebesar-besarnya kesejahteraan rakyat.

Penulis melihat masih ada keluhan masyarakat terkait dengan pelayanan BPN. Di sisi lain, masih rendahnya pengetahuan masyarakat tentang proses, prosedur, mekanisme, dan persyaratan untuk memeroleh sertifikat. Untuk itu, penulis mencoba mengkaji fenomena ini melalui pandangan komunikasi dan motivasi kerja Aparaturnya.

\section{Tinjauan Konseptual}

Secara konsepsional, komunikasi dan motivasi kerja memengaruhi kinerja pelayanan, seperti Teori 


\section{Gambar 1 \\ Model "Performance" dengan "Sufficient Factors" Lengkap Menurut Clay Carr}

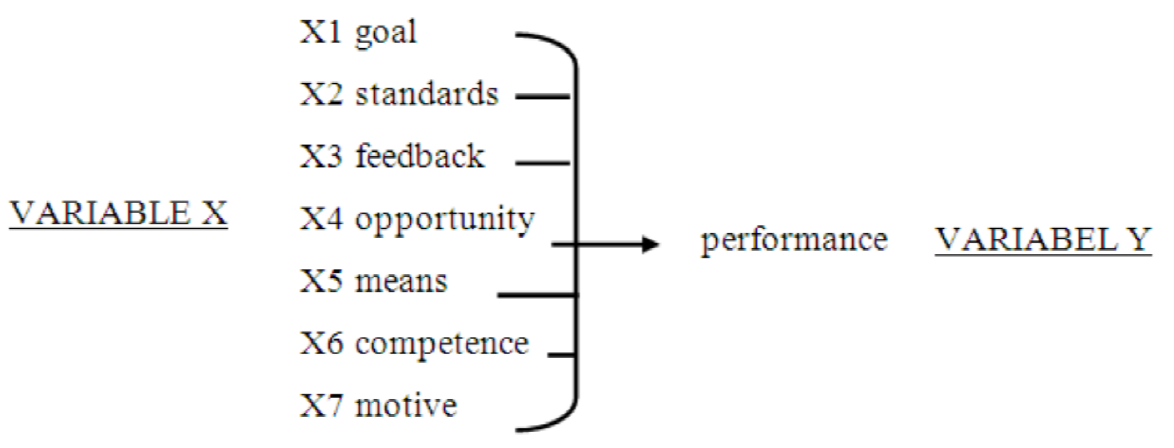

Sumber: Ndraha (2007:62-63) Kybernologi Sebuah Profesi

kinerja Car dalam Ndraha (2007: 62-63), jika kinerja (performance) diposisikan sebagai devendent variable, maka ia bergantung pada atau dipengaruhi oleh beberapa faktor indevendent variable, dan digambarkan pada gambar 1 .

Selanjutnya Sharif dan Kawan-kawan (1981:348) menyatakan bahwa dimensi kerja Pegawai meliputi: quality, quantity, inisiative, adoptibility dan communications.

\subsection{Komunikasi} bahwa:

Cofesio dan Morhouse (1998:38) menyatakan

understanding is the key which influences individuals or groups to take positive action to achieve spesicific goals the real essence of what leader do. Good communication is the key of good communication is the key of understanding.

Sehingga, Cangara (2002:1) menyatakan bahwa komunikasi sudah merupakan bagian dari kehidupan manusia seperti halnya bernapas.

Namun Littlejohn (2002:6) menyatakan, "Communication is difficult to define."

Secara agak lebih operasional, Ruben (1998:16) menyatakan:

We can combine these fundamentals to derive the following definition or communication:
Human is the process through, which individuals - in relationships, groups, organizations, and societies - respond to and create messages to adapt to the environment and one another. This definition is helpful for thinking about the nature of communication and for explaining it in fairly straight forward terms to others.

Pendapat Ruben ini menyatakan bahwa komunikasi manusia sebagai proses dari individu, dalam hubungan-hubungan, kelompok-kelompok, organisasi-organisasi, dan masyarakat-masyarakat merespons dan menciptakan pesan-pesan untuk beradaptasi terhadap lingkungan dan sesama.

Sejalan dengan itu, tentang komunikasi sebagai proses Sarah Trenholm dan Arthur Jensen (1996:4) mendefinisikan komunikasi "A Process by which a Source transmits a message to a receiver through some channel." Gode (1996:5) memberi pengertian mengenai komunikasi, sebagai: "It is process that makes common to or several what was the monopoly of one or some."

Secara linier, proses komunikasi, menurut Liliweri (1997:23), sedikitnya melibatkan empat elemen atau komponen sebagai berikut: (1) Sumber/ pengirim pesan/komunikator; (2) Pesan; (3) Saluran; dan (4) Penerima/komunikan.

Selain keempat elemen tersebut (lazim disebut 
sebagai model S-M-C-R atau Source-ChannelReceiver), Senjaya (1993:31) menambahkan, ada tiga elemen atau faktor lainnya yang juga penting dalam proses komunikasi, yakni: (1) Akibat/ dampak/hasil yang terjadi pada pihak penerima/ komunikan; (2) umpan-balik/feedback, yakni tanggapan balik dari pihak penerima/ komunikan atas pesan yang diterimanya; dan (3) Noise (gangguan), yakni faktor-faktor fisik ataupun psikologis yang dapat mengganggu atau menghambat kelancaran proses komunikasi.

Efektif--tidaknya keterlibatan komponenkomponen tersebut, Nawawi (1994:22) menyatakan bahwa komponen-komponen tersebut merupakan suatu kesatuan yang utuh yang saling mendukung dan integratif menentukan keberhasilan komunikasi. Oleh sebab itu, diperlukan pemahaman yang lengkap mengenai rincian dan esensi yang terkandung dalam setiap komponen dialog.

\subsection{Motivasi Kerja}

Hersey dan Blanchard (1993:21) berpendapat bahwa "motivation is will to do the whys of behaviour”. Sedangkan Mangkunegara (2006:61), menjelaskan, motivasi merupakan kondisi atau energi yang menggerakkan diri karyawan yang terarah atau tertuju untuk mencapai tujuan organisasi. Hal itu juga didukung pendapat Gellerman (1983:15), yaitu "Motivation is any action that couse someone Behaviour to change. Dengan demikian, motivasi adalah pendorong seseorang untuk berbuat, bertindak dan berperilaku.

Motivasi tersebut tidak terlepas dari faktor pendorong mengapa, misalnya manusia berperilaku, berbuat, atau bertindak. Faktor pendorong ini seringkali dihubungkan dengan kepentingan atau kebutuhan manusia.

\subsection{Motivasi}

Selanjutnya mengenai teori-teori motivasi, Gibson, et. al (1989:97) menyatakan bahwa teoriteori motivasi mengacu kepada content theories (teori kepuasan), yang memusatkan perhatian kepada faktor dalam diri orang yang menguatkan (energize), yang menggerakkan (direct), mendukung (substancy), dan menghentikan (stop) perilaku pegawai.

Pada penelitian ini pembahasan dibatasi pada teori MacGregor dalam Gito Sudarmo (1986:83) yang menyatakan bahwa manusia dewasa secara alamiah senang bekerja, mau berinisiatif, bekerjasama secara produktif maupun bertanggung jawab terhadap tugas dan kewajiban, serta selalu disiplin, dan berusaha untuk berprestasi sesuai bidangnya.

\subsection{Kulitas Pelayanan}

Tugas Pemerintah, antara lain, memberikan pelayanan. Dalam kaitannya ini, Ndraha (1997:73) menyatakan bahwa pemerintah adalah Badan yang memroduksi, mendistribusikan atau menjual alat pemenuhan kebutuhan Rakyat berbentuk jasa public, dan layanan sivil.

Oleh karena itu, setiap melaksanakan tugas dan kewajibannya, aparatur pemerintah diharapkan menempatkan dirinya sebagai pelayan masyarakat dan bukan sebaliknya.

Hal ini sesuai pendapat Rasyid (1997:14), bahwa:

Pemerintah bukanlah lapangan pekerjaan yang menjanjikan kesenangan hidup material yang berlebihan bagi Aparatur, karena kebutuhan pengabdian dan pelayanan yang diharapkan dari mereka justru adalah bagaimana memberikan kesenangan kepada orang banyak. Dengan demikian, seseorang yang masuk bekerja di lingkungan pemerintahan dengan motivasi untuk menjadi kaya pasti salah pilih.

Dengan demikian, peranan aparatur dalam memberikan pelayanan kepada masyarakat bukan untuk kepentingan pribadi dan golongannya, tetapi terutama kepentingan kemanusiaan terhadap masyarakat secara keseluruhan, seperti, dikatakan Supriyanto (1997:104) bahwa Aparatur Pemerintah harus memiliki 3 (tiga) aspek penting, yaitu: Memiliki tanggung jawab, responsif, komunikatife, dan konsisten.

\subsection{Kualitas Pelayanan Sertifikat Tanah}

Menurut pendapat Asmadi Adnan (2007:5), indikator-indikator yang memengaruhi tinggi- 
rendahnya kinerja pelayanan pertanahan dikelompokkan menjadi 5(lima) kelompok, yaitu: inputs, outputs, outcomes, impact dan benefits.

Inputs-inputs sebagai faktor yang mempengaruhi pelayanan adalah: 1) Kebijakan Pelayanan Pertanahan (Prosedur, Persyaratan, jangka waktu, biaya, dsb), 2) Sumber Daya Manusia (SDM), 3) Prasarana dan sarana kerja, 4) Data-data Pertanahan, 5) Kondisi daerah (luas \& geografis wilayah), 6) Kondisi sosial ekonomi masyarakat, 7) Aksesibilitas ke Kantor Pertanahan, 8) Pengenaan BPHTB/pajak terkait lainnya, 9) Pungutan biaya oleh pihak terkait lainnya dalam pengurusan tanah, 10) dan sebagainya.

Kecuali hal tersebut, menurut Renstra Kanwil BPN DKI Jakarta, adalah faktor SDM. Dalam hal ini, semangat aparatur dan faktor komunikasi merupakan faktor yang menentukan tinggirendahnya kualitas pelayanan. Selanjutnya, bagaimana mengukur atau menilai kualitas pelayanan yang diberikan birokrasi pemerintahan kepada masyarakat, Berry, et al, Lovelock (1992:225) menyatakan bahwa sulit untuk mengukur kualitas pelayanan, tidak ada suatu standar yang dapat dipakai sebagai ukuran umum tentang kualitas pelayanan.

\section{Metode Penelitian}

Dalam penelitian ini, penulis menggunakan desain penelitian eksplanatory survey, dengan teknik path analisys dan menggunakan sarana uji statistik untuk mengetahui besaran pengaruh Variabel Komunikasi (X1) dan Motivasi Kerja (X2), terhadap kualitas pelayanan sertifikat (Y). Untuk melengkapi analisis penelitian ini juga menggunakan pendekatan kualitatif dengan melalui observasi partisipan dan wawancara dengan informan yang dinilai representatif. Hal ini dilakukan untuk mengecek kembali, terutama tentang kualitas pelayanan sertifikat tanah menurut persepsi masyarakat penerima layanan sertifikat di wilayah penelitian.

Sedangkan Variabel-variabel yang diteliti serta dimensi-dimensi dalam penelitian ini dapat dilihat secara operasionali sebagai berikut:

(1) Komunikasi $\left(\mathrm{X}_{1}\right)$ (Harold D. Lasswell dalam
Wilbur Scramm (1971:84): kualitas komunikator, pesan, Media/saluran, dan, efek.

(2) Motivasi kerja $\left(\mathrm{X}_{2}\right)$ (Mc Gregor dalam Gito Sudarmo (1986:83): senang bekerja, inisiatif/ prakarsa, kerjasama, disiplin, prestasi.

(3) Kualitas Pelayanan (Y) Ndraha (2005:15): kesederhanaan, kejelasan, kepastian waktu, akurasi, keamanan, tanggung jawab, kelengkapan sarana dan prasarana, kemudahan akses, kedisiplinan, kenyamanan.

\section{Pembahasan}

\subsection{Pengaruh Komunikasi terhadap Kualitas Pelayanan Sertifikat Tanah}

Faktor komunikasi dan motivasi kerja berpengaruh signifikan terhadap kualitas pelayanan sertifikat tanah di Kantor Pertanahan Kota Madya Jakarta Selatan. Hal tersebut sebagaimana hasil penelitian dibawah ini.

Pada dasarnya, komunikasi dan motivasi kerja berpengaruh terhadap kualitas pelayanan sertifikat tanah di Kantor Pertanahan Kota Madya Jakarta Selatan. Hasil penelitian menunjukkan bahwa dari empat dimensi komunikasi, dimensi kualitas komunikator dinilai paling rendah, yaitu $76 \%$, dan paling tinggi, yaitu pada dimensi gangguan, yaitu $85 \%$. Selanjutnya, motivasi kerja, dimensi tanggung jawab, mendapatkan nilai paling rendah, yaitu $79 \%$, bila dibandingkan dengan lima dimensi lainnya dan yang mendapatkan nilai paling tinggi adalah dimensi inisiatif/prakarsa yaitu $88 \%$.

Demikianlah, secara kuantitatif hasil penelitian signifikan dan dapat diterima. Komunikasi berpengaruh terhadap kualitas pelayanan dan mengandung arti semakin tinggi/baik komunikasi dilakukan, maka akan semakin tinggi/baik kualitas pelayanan sertifikat dan sebaliknya.

Dengan demikian, karena komunikasi memberikan kejelasan informasi maka pencapaian tujuan akan lebih mudah tercapai. Berdasarkan penjelasan narasumber dan pengecekan di lapangan, jumlah komunikator belum sebanding dengan jumlah pemohon sertifikat.

Di samping itu, media komunikasi tertulis (tercetak seperti brosur, leaflet, spanduk, papan 
Terakreditasi Dirjen Dikti SK No. 56/DIKTI/Kep/2005

\section{Koefisien korelasi, Jalur dan Determinasi antara Komunikasi terhadap Kualitas Pelayanan}

\begin{tabular}{|c|l|l|l|}
\hline No. & \multicolumn{1}{|c|}{ Koefisien } & Notasi & Besar Koefisien \\
\hline 1. & Koefisien Korelasi $\mathrm{X}_{1}$ dan $\mathrm{X}_{2}$ dengan $\mathrm{Y}$ & $\mathrm{R}_{\mathrm{yx}}$ & 0,87 \\
\hline 2. & Koefisien Jalur $\mathrm{X}_{1}$ dan $\mathrm{X}_{2}$ terhadap $\mathrm{Y}$ & $\mathrm{P}_{\mathrm{yx}}$ & 0,76 \\
\hline 3. & Koefisien Determinasi $\mathrm{X}_{1}$ dan $\mathrm{X}_{2}$ terhadap $\mathrm{Y}$ & $\mathrm{R}^{2} \mathrm{yx}$ & 0,87 \\
\hline
\end{tabular}

pengumuman) masih tidak cukup tersedia, baik di kelurahan, di kecamatan, di ruang tunggu pelayanan, maupun di masing-masing seksi di Kantor Pertanahan Kota Madya Jakarta Selatan.

Menurut observasi penulis dan dari hasil wawancara serta diskusi beberapa orang pemohon maupun pendapat narasumber lainnya, ternyata sebagian besar pemohon tidak paham bahwa untuk memeroleh sertifikat tanah harus mengajukan permohonan tiga kali, dan sering terjadi pengulangan berkas permohonan. Kekurangtahuan tersebut disebabkan karena kurang ketersediaan dan ketercukupan maupun keberlanjutan dari media seperti disebutkan, yaitu media secara lisan, tertulis, tercetak, audio, maupun audio visual, serta belum optimalnya peralatan teknologi dan gambar petunjuk/papan informasi maupun brosur mekanisme permohonan sertfikat untuk tiap-tiap seksi.

Dari segi komunikator maupun sikap (attitude) di dalam berkomunikasi, kadang-kadang ditemui bahwa beberapa petugas kurang ramah dan kurang sabar. Permintaan dengan menggunakan kalimat: "Mohon Bapak/Ibu melengkapi persyaratan KTP", jarang dilakukan petugas. Berdasarkan observasi dokumen bahwa tujuan dan fungsi komunikasi dalam penyelenggaraan pelayanan tersebut belum terlaksana secara maksimal antara lain, karena kurangnya media komunikasi yang dapat diperoleh oleh pemohon.

Demikianlah bahwa kecuali berbagai faktorfaktor memengaruhi pelayanan, maka unsur komunikasi dapat menambah atau mengurangi kualitas pelayanan. Bahwa salah satu faktor yang diperlukan untuk mencapai tujuan adalah komunikasi yang berkualitas dan yang optimal dalam arti komunikasi yang harus dikembangkan dan diatur secara baik oleh organisasi pelayanan dalam hal ini di Kantor Pertanahan Kota Madya Jakarta Selatan.

Berdasarkan observasi secara partisipatoris di lapangan, ditemukan kenyataan bahwa sejak akhir tahun 2007, kecuali dilakukan berbagai perubahan fisik seperti penataan ruangan untuk kepala-kepala seksi untuk memudahkan komunikasi yang diletakkan dalam satu lantai, juga telah dipergunakan teknologi Land Office Computerization (LOC) yang terintegrasi. Untuk mengoperasionalkan LOC ini, diawali dengan adanya petugas desk information diberikan kode antrian melalui nomor elektronik, disediakan touch screen yang berisi informasi mengenai tahapan, serta lengkap tidaknya berkas kepengurusan yang dapat diakses dengan menggunakan berkas dan PIN yang bersifat privacy, serta pengumuman melalui LOC bagi sertifikat yang telah selesai dan diterbitkan.

Kelengkapan teknologi tersebut belum maksimal berfungsi karena kurangnya komunikator sebagai penerima tamu, pemandu dan petunjuk letak serta petunjuk peralatan dan petunjuk operasional peralatan, tidak sepenuhnya dimanfaatkan, terutama oleh pemohon perseorangan. Demikianlah bahwa secara normatif keterlibatan unsur-unsur komunikator, pesan, dan saluran/media untuk meminimalisasi gangguan dalam proses untuk memeroleh kesamaan makna, kesamaan pengertian sehingga diperoleh penerimaan yang baik bagi masyarakat yang mengurus sertifikat, telah dilakukan untuk memeroleh pelayanan yang sebaik-baiknya. Namun, karena kuantitas komunikator yang terdiri 
atas penerima tamu dan pemandu tidak cukup, serta petunjuk manual untuk mengoperasionalkan peralatan operasional LOC belum dimanfaatkan secara optimal, komunikasi sebagai proses masih mengalami gangguan.

Berhubung penanganan gangguan belum melembaga, sehingga masalah setting tempat untuk berkomunikasi kurang terjamin serta kepastian jadwal masih merupakan hambatan, yang pada akhirnya komunikator kurang dapat melaksanakan tugasnya. Ketersediaan jumlah media baik tertulis/ tercetak maupun audio/audio visual kurang memadai, serta fasilitas internet, email, LOC belum berfungsi sepenuhnya.

\subsection{Pengaruh Motivasi Kerja terhadap Kualitas Pelayanan Sertifikat Tanah}

Hasil penelitian ini mengindentifikasikan bahwa perubahan-perubahan pada motivasi kerja dapat memengaruhi kualitas pelayanan di Kantor Pertanahan Kota Madya Jakarta Selatan. Lebih lanjut dapat dikatakan bahwa dalam penyusunan strategi peningkatan kualitas pelayanan, motivasi kerja menjadi sesuatu yang harus dipertimbangkan, karena motivasi kerja memiliki pengaruh langsung terhadap kualitas pelayanan sertifikat tanah di Kantor Pertanahan Kota Madya Jakarta Selatan, yaitu sebesar 0,69\%. Enam dimensi motivasi yang dipertimbangkan dalam hubungannya dengan kualitas pelayanan yaitu senang bekerja, inisiatif, kerjasama, tanggung jawab, disiplin, dan prestasi.

Demikianlah bahwa variabel motivasi berpengaruh kepada kualitas pelayanan, dan memiliki kontribusi $69 \%$.

Sedangkan hasil konfirmasi melalui pengamatan dan wawancara mendalam terhadap narasumber, rasa enggan, dan gambaran negatif dalam proses pelayanan yang akan dihadapi, masih terus dirasakan oleh masyarakat ketika mereka harus berurusan dengan lembaga pemerintah dalam hal ini pelayanan di bidang pertanahan.

Berkaitan dengan motivasi kerja pegawai bahwa rendahnya motivasi, antara lain, tampak pada komersialisasi tugas atau jabatan yang dilakukan petugas. Dorongan untuk menyelesaikan tugas bukan lagi oleh motivasi atau semangat kerjanya yang tinggi, tetapi semata-mata karena materi atau untuk kepentingan tertentu.

Hal ini tampak bahwa $90 \%$ dari urusan sertifikat oleh pemohon diselesaikan melalui pihak ke 3 yaitu biro jasa atau badan hukum, maupun calo di Kantor Pertanahan Kota Madya Jakarta Selatan, sehingga bagi pemohon yang memiliki potensi, lebih memilih pihak ketiga yaitu biro jasa tertentu untuk membantu penyelesaian urusannya dengan suatu unit pelayanan pemerintah.

Meskipun bermunculan berbagai biro jasa yang menyediakan jasa membantu pengurusan dokumen membawa dampak positif bagi penyediaan lapangan kerja baru, namun dari sisi kinerja pelayanan publik, hal ini merupakan suatu indikator rendahnya kualitas pelayanan.

Masih banyaknya biro jasa yang memberikan bantuan jasa pengurusan pelayanan tersebut dan tetap eksis sampai saat ini, menunjukkan bahwa masih belum berhasilnya pemberian pelayanan yang prima dan memuaskan bagi warga negara memerlukan atau kualitas pelayanan belum dapat meningkat.

Greenberg dan Baron (1993:114) menyatakan bahwa motivasi merupakan suatu proses yang mendorong, mengarahkan, dan memelihara perilaku manusia ke arah pencapaian tujuan. Sedangkan mengenai faktor-faktor yang memengaruhi motivasi kerja personil, menurut pendapat Sutermeister (1976:5), terdiri atas tiga unsur besar, yaitu kondisi fisik lingkungan kerja (physical working condition), kondisi sosial lingkungan (social working condition), dan keterpenuhan kebutuhan dasar individu (fulfillment of individual basic need). Selanjutnya Schermenharn (2003:442) mengemukakan bahwa kunci keberhasilan pengembangan motivasi adalah melalui pemberian imbalan (reward), yang bernilai dan berkaitan dengan kemajuan kinerja yang didistribusikan secara berkeadilan. Menurut pendapatnya, imbalan secara formal dapat didefinisikan sebagai hasil kerja yang bernilai positif bagi individu " $A$ reward is formally defined as work outcome of positive value to the individual."

Berkaitan dengan imbalan para PNS yang bertugas di BPN, memang terbatas karena sudah 
ditentukan dalam PGPS (Peraturan Gaji Pegawai Sipil) yang bersifat standar dan perbaikannya dihadapkan kepada kemampuan keuangan negara yang masih terbatas. Sehubungan dengan itu di BPN, selaku pegawai Negari motivasi, terutama terkait dengan kesadaran dan hati nurani sebagai karyawan dalam melaksanakan tugas pengabdian sebagai abdi masyarakat dan abdi negara bagi bangsa dan negara, melayani bagi masyarakat yang memerlukan.

Sesuai pendapat Tjokroamidjoyo (1989:248), tanpa motivasi atau semangat kerja yang tinggi hanya menunggu perintah dan kurang inisiatif, dan kurang tanggung jawab, semuanya itu tidak berorientasi kepada prestasi dan tanggung jawab.

Selanjutnya, motivasi kerja yang rendah berpengaruh terhadap proses pencapaian tujuan, sedangkan semangat yang tinggi berfaedah bagi kepentingan organisasi. Karena itu, motivasi kerja pegawai merupakan faktor penting dalam upaya pencapaian tujuan organisasi. Hal tersebut juga sejalan dengan pendapat James L Perry and Lois R Wise (1999:367-731) yang menyatakan bahwa

"Public service motivation is importen not just to motivation but also to productivity, improved management practices, accountability, and trust in government, making it one of the major current topics of investigation in public administration."

Demikianlah motivasi itu memengaruhi kinerja pegawai dalam pelayanan publik. Bahwa motivasi kerja tidak terlepas dari apa dan mengapa semangat kerja itu dibutuhkan, apakah yang mendorongya dan mengapa seseorang dituntut untuk memiliki motivasi yang tinggi guna mencapai tujuan organisasi pada setiap organisasi khusus pemerintahan. Para pegawai tidak hanya diharapkan cerdas, mampu, dan cakap dalam pekerjaan, tetapi juga mereka harus memiliki kerja yang tinggi untuk mendahulukan kepentingan publik.

\subsection{Pengaruh Komunikasi dan Motivasi Kerja terhadap Kualitas Pelayanan}

Berdasarkan pendekatan kuantitatif tampak bahwa secara bersama-sama komunikasi dan motivasi kerja terbukti memiliki pengaruh terhadap kualitas pelayanan sertifikat tanah di Kantor Pertanahan Kota Madya Jakarta Selatan.

Hasil penelitian ini sejalan dengan berbagai pendapat yang dikemukakan Carr, Richard M Steers, Sharif, Smith, dan Kochler, karena kinerja pelayanan, antara lain, dipengaruhi oleh motivasi dan komunikasi.

Berdasarkan pengamatan di lapangan, walaupun memang telah didasari oleh konstitusi, undang-undang, dan peraturan lainnya serta dijabarkan melalui renstra, ternyata, antara lain, karena faktor komunikasi dan motivasi, maka kualitas pelayanan pertanahan, khususnya di Kantor Pertanahan Kota Madya Jakarta Selatan, belum maksimal.

Sehubungan dengan itu, seperti uraian pada latar belakang masalah, fokus penelitian ini mengkaji faktor belum optimalnya komunikasi dan lemahnya motivasi kerja pengaruhnya terhadap pelayanan publik di bidang pertanahan.

Hasil kuantitatif mengindikasikan bahwa perubahan-perubahan secara bersama-sama pada komunikasi dan motivasi kerja berpengaruh terhadap kualitas pelayanan sertifikat tanah di Kantor Pertanahan Kota Madya Jakarta Selatan.

Lebih lanjut dapat dikatakan bahwa dalam upaya peningkatan kualitas pelayanan, komunikasi, dan motivasi, menjadi suatu pertimbangan yang sangat penting, karena telah terbukti bahwa terdapat pengaruh langsung secara bersama-sama antara komunikasi dan motivasi kerja terhadap kualitas pelayanan sertifikat tanah di Kantor Pertanahan Kota Madya Jakarta Selatan, yaitu sebesar 0,87 .

Hal tersebut di atas terkait dengan dimensi komunikasi dan motivasi kerja yang dipertimbangkan dalam hubungannya dengan kualitas pelayanan, karena hasil penelitian menunjukkan bahwa secara sendiri-sendiri maupun secara bersama-sama meningkatan dan atau menurunkan kualitas pelayanan.

Untuk meningkatkan efisiensi dan efektivitas penyelenggaraan pelayanan publik di bidang pertanahan tersebut sejalan dengan prinsip-prinsip pelayanan prima, Badan Pertanahan Nasional 
Republik Indonesia (BPN-RI) telah melakukan banyak perbaikan dan penyederhanaan kebijakan pelayanannya, antara lain: (1) Instruksi MNA/ KBPN No. 3/1998 tentang Peningkatan Efisiensi dan Kualitas Pelayanan Masyarakat di Bidang Pertanahan; (2) PP No. 48/2002 tentang TarifAtas Jenis Penerimaan Negara Bukan Pajak yang Berlaku pada BPN; (3) Keputusan KBPN No.1/2005 tentang Standar Prosedur Operasional Pelayanan Pertanahan (SPOPP), dan sebagainya. Kebijakan ini diharapkan mampu meningkatkan kinerja Kantor Pertanahan Kabupaten/Kota dalam mengelola pelayanannya sesuai dengan kondisi dan keinginan masyarakat di daerahnya.

Namun demikian, sampai saat ini masih ada pihak menilai bahwa kinerja pelayanan pertanahan belum dapat terselenggara secara optimal dan dapat dipercaya sesuai harapan. Hal tersebut, di antaranya, ditunjukkan dengan masih banyaknya: (1) sisa/tunggakan permohonan yang belum mampu diselesaikan dalam waktu yang telah ditentukan; (2) kepastian waktu yang kurang jelas; (3) muncul dan berkembangnya berbagai masalah sengketa konflik pertanahan baik kuantitas, kualitas, maupun jenisnya, dan sebagainya.

Tinggi rendahnya pelayanan menurut Asmadi Adnan (2007:5), ditentukan oleh sejumlah indikator, sebagai berikut:

(1) Indikator inputs (masukan) pelayanan pertanahan, yaitu terdiri atas sub indikator prosedur, persyaratan, jangka waktu, biaya, SDM, sumber pembiayaan, prasaran/sarana kerja, data-data pertanahan, pengenaan BPHTB/pajak terkait lainnya, pungutan biaya lainnya di Kantor Desa/Kelurahan/Camat terkait pelayanan, kondisi daerah, kondisi sosial ekonomi masyarakat, dan aksesibilitas;

(2) Indikator outputs (keluaran) pelayanan pertanahan, yaitu terdiri atas sub indikator penerbitan surat ukur/gambar ukur dan sertifikat tanah;

(3) Indikator outcomes (hasil) pelayanan pertanahan, yaitu terdiri atas sub indikator menjamin kepastian hukum hak atas tanah, penyediaan informasi pertanahan, dan tertib administrasi pertanahan;
(4) Indikator benefits (manfaat) pelayanan pertanahan, yaitu terdiri atas sub indikator pemanfaatan sertifikat tanah (hak tanggungan) dan dampak pensertifikatan tanah terhadap nilai, posisi tawar, dan sebagainya.

Disamping itu, di lapangan ditemui bahwa terdapat pengaduan oleh masyarakat terhadap pelayanan yang diberikan.

Pengaduan oleh masyarakat berkaitan dengan pelayanan pertanahan, baik secara langsung oleh masyarakat ke Badan Pertanahan Nasional maupun tidak langsung melalui lembaga DPR, Komnas HAM, Komisi Ombudsman Nasional maupun lembaga-lembaga swadaya masyarakat, dapat dikelompokkan ke dalam beberapa aspek, yaitu: terkait dengan penyimpangan dalam prosedur, persyaratan, waktu, dan biaya.

Berdasarkan pengamatan di lapangan dan wawancara mendalam, diperoleh fakta bahwa komunikasi dan motivasi kerja pengaruhnya belum optimal, antara lain karena: sikap masyarakat, sumber daya manusia, sarana prasarana, pengetahuan masyarakat terhadap pertanahan dan permintaan pelayanan yang cenderung meningkat serta tidak lengkapnya data.

(1) Sikap Masyarakat (Pelanggan)

Sikap masyarakat yang lebih memilih biro jasa (baik resmi maupun tidak resmi) daripada berhubungan langsung dengan Instansi Kantor Pertanahan mendorong pelayanan tidak optimal.

(2) Sumberdaya Manusia

Kualitas petugas sangat menentukan berfungsi tidaknya pelayanan. Jika petugas mempunyai kemampuan manajerial komunikasi maka pelayanan akan efektif dan memuaskan pelanggan.

(3) Sarana dan Prasarana

Sarana dan prasarana yang pokok dalam menunjang peningkatan pelayanan di bidang pertanahan masih dirasakan kurang, sehingga berakibat pada rendahnya kuantitas pelayanan. Seperti peta dasar, peralatan komputer, ruang kantor yang memadai dan lainnya masih perlu mendapat perhatian. 
(4) Pengetahuan Masyarakat terhadap Hukum Pertanahan

Masyarakat kurang memahami berbagai ketentuan dalam pengurusan pelayanan pertanahan, yang pada akhirnya berpengaruh terhadap kecepatan Kantor Pertanahan dalam memberikan pelayanan kepada Masyarakat.

(5) Permintaan Pelayanan yang Cenderung Meningkat

Kebutuhan masyarakat yang selalu meningkat, terjadi ketidakseimbangan antara permintaan masyarakat dengan pelayanan yang diberikan Kantor Pertanahan.

(6) Tidak Lengkapnya Data

Pengajuan berkas permohonan pelayanan oleh masyarakat dapat segera diproses apabila data permohonan tersebut sudah lengkap dan jelas. Seringkali kelengkapan persyaratan yang menjadi kebutuhan mutlak dalam proses pelayanan, kurang disadari oleh masyarakat, sehingga berkas permohonan tidak dapat diproses.

\subsection{Analisis Epsilon}

Secara kuantitatif, faktor komunikasi dan motivasi kerja berpengaruh signifikan terhadap kualitas pelayanan sertifikat tanah di Kantor Pertanahan Kota Madya Jakarta Selatan. Sedangkan hasil konfirmasi berdasarkan observasi dan wawancara mendalam kepada narasumber diperoleh temuan terkait dengan komunikasi, dikemukakan bahwa karena kurangnya keterbukaan informasi serta tingkat kemampuan manajerial komunikasi yang belum maksimal, antara lain belum tercukupinya tempat, jadwal, dan belum tersebarnya media secara merata, maka keluhankeluhan ketidakpuasan masyarakat yang menyatakan bahwa pengurusan sertifikat terkesan lama, berbelit-belit, tidak jelas, dan segudang permasalahan lain yang mewarnai pengurusannya, yaitu seakan-akan hal tersebut disengaja oleh pihak-pihak yang mengambil keuntungan, sehingga menimbulkan dampak orang enggan mengurus hak atas tanah dan memperoleh kepastian hukum atas bidang tanah yang dikuasainya.
Hal tersebut di antaranya ditunjukkan oleh adanya kenyataan masih adanya sisa/tunggakan permohonan yang belum mampu diselesaikan dalam waktu yang telah ditentukan serta muncul dan berkembangnya berbagai masalah sengketa dan konflik pertanahan baik kuantitas, kualitas maupun jenisnya.

Secara teoretis, dalam melaksanakan tugas dan kewajibannya aparatur pemerintah memang harus patuh terhadap peraturan-peraturan, khususnya standar minimum pelayanan yang telah ditentukan seperti faktor-faktor inputs yaitu: goal, activity, opportunity, competence, mean, motivasi communication maka tetap saja kualitas pelayanan menjadi rendah.

Di bidang pertanahan, karena masalahmasalah kepatuhan terhadap standar belum sepenuhnya diterapkan, maka konflik tanah tak pernah berakhir. Kasus Tanjungmorawa, Cianjur, Jember, Bulukumba, Atang Sanjaya, Meruya Selatan, dan Pasuruan, hanyalah beberapa contoh konflik pertanahan yang terjadi. Pada kenyataannya, hampir di seluruh penjuru Tanah Air, konflik semacam ini masih menjadi persoalan. Jika ditelisik, semua kasus sengketa tanah yang terjadi menunjukkan pola sengketa yang sebangun. Berbagai kasus pertanahan yang menyangkut nasib ribuan warga itu pun dikenal memakan waktu lama dan terasa menggetirkan dalam proses penyelesaiannya.

Terjadinya fenomena tersebut, antara lain belum adanya kepatuhan aparatur terhadap ketentuan-ketentuan persyaratan dan prosedur standar minimum pelayanan, terutama karena belum adanya kesadaran bahwa masuk di lingkungan birokrasi bukanlah lapangan yang menjanjikan kesenangan, tetapi kebutuhan untuk pengabdian kepada orang banyak dan dalam melaksanakan tugas dan kewajiban untuk bahwa menempatkan dirinya sebagai pelayan masyarakat dan bukan sebaliknya.

Selain harus memiliki tanggung jawab selaku abdi negara dan abdi masyarakat belum diterapkannya budaya malu, serta semangat untuk melayani kepentingan umum sebagai dasar dari motivasi mereka memilih karier di Pemerintahan, 
belum ada.

Untuk memberikan tekanan kepada kesadaran ini, terutama melalui komunikasi yang harus dikembangkan secara sistematis dan melembaga lewat sebuah wadah kegiatan, sehingga menjamin adanya ketersediaan, keterkecukupan, serta keterlanjutan, baik komunikator, pesan, saluran, agar dapat mengatasi gangguan dalam proses komunikasi. Di samping itu, tekanan terhadap motivasi kerja, yaitu melalui pengawasan eksternal, dengan social control masyarakat terhadap penyelenggara pelayanan publik, meliputi pengaturan yang lebih jelas dan tegas terhadap Kode Etik Perilaku Petugas Pelayanan Publik serta perlu aturan tentang standar pengelolaan keluhan publik, sehingga menjadi payung dan pedoman untuk menyelesaikan keluhan masyarakat, dan tindak lanjutnya.

Selain itu dengan telah diterapkannya teknologi informasi dalam peningkatan proses penyelenggaraan dan penyelesaian sertifikat tanah, maka proses tatap muka langsung antara aparat dengan petugas diharapkan dapat semakin dikurangi, sehingga tidak memungkinkan munculnya pikiran dan perbuatan negatif sekaligus menjatuhkan citra Kantor Pertanahan, karena telah meninggalkan rekaman jejak yang tidak sensitif, tidak akomodatif, dan tidak dipercaya terkait dengan tuntutan transparansi dan akuntabilitas.

Dari faktor-faktor yang memengaruhi kualitas pelayanan pertanahan, menurut Asmadi Adnan ini, mengenai faktor prosedur persyaratan, fenomena yang muncul tetapi belum tertampung secara yuridis formal terkait dengan tugas BPN adalah masalah yang berhubungan dengan elevasi tanah di kota, mempertinggi permukaan tanah untuk menyelamatkan bangunan dari musibah banjir di lokasi rumah atau lokasi tertentu, tetapi karena belum diatur mengenai hak dan kewajiban apa yang harus dipenuhi dapat mengakibatkan musibah atau banjir di bangunan atau lokasi lain. Juga ground flow yang mulai muncul di kota-kota besar membangun flat atau rumah susun yang menjulang tinggi terdiri atas bagian bawah terus ke atas, semakin tinggi apabila terjadi sesuatu yang tidak diinginkan dapat menanggung risiko lebih dari yang di bawah, dalam hal ini juga belum diatur oleh aturan yang ada.

Disamping itu, keputusan tentang pengadaan tanah demi kepentingan umum peraturan yang mengatur kurang terinci, masih sering dapat disalahartikan. Misal, pengadaan tanah untuk industri yang bersifat provitable, tetapi dianggap pengadaan tanah adalah untuk kepentingan sosial, misal untuk jalan tol atau industri, perlu diantisipasi dengan ganti untung sesuai Nilai Jual Objek Pajak.

\section{Penutup}

\subsection{Kesimpulan}

Temuan yang diperoleh adalah bahwa komunikasi akan lebih berpengaruh dengan dukungan keterbukaan yang kondusif melalui wadah yang melembaga secara sistimatis, sehingga diperoleh ketersediaan, ketercukupan, dan keberlanjutan komunikator, pesan, media.

Hasil penelitian menguatkan teori komunikasi Lass Well dan teori motivasi kerja MacGregor, di mana komunikasi akan lebih efektif kecuali komunikasi sebagai keterampilan yang melibatkan faktor diterminasi komunikator, pesan, media, dan gangguan. Efektivitas komunikasi akan terjadi apabila disertai dengan keterbukaan yang kondusif yang diwadahi oleh suatu kelembagaan yang bekerja sistematis.

\subsection{Saran}

(1) Saran Akademik

Penelitian tentang komunikasi dan motivasi kerja serta kualitas pelayanan sertifikat, masih langka. Perlu ditingkatkan dengan menggunakan teori dan konsep lain, sehingga akan diperoleh konsep dan teori baru untuk memperkuat teori yang sudah ada, bahkan untuk memperbaiki/menggugat teori yang sudah ada.

Penelitian merekomendasikan perlunya dilakukan penelitian terhadap faktor-faktor lain yang tidak diteliti dalam penelitian ini, agar di masa yang akan datang tercapai kualitas pelayanan sertifikat yang lebih maksimal. 
(2) Saran Operasional

Untuk meningkatkan kualitas pelayanan kepada masyarakat, di bidang komunikasi perlu pewadahan secara melembaga, sehingga dapat memenuhi kualitas dan kuantitas, dari dimensi dan komunikasi yang diperlukan untuk berproses secara berlanjut.

Perlu pengembangan komunikator sebagai tenaga fungsional yang bertanggung jawab langsung kepada Kepala Badan Pertanahan Nasional di setiap tingkatan dan aplikasi teknologi informasi untuk mendukung pelayanan Sertifikat Tanah.

Sedangkan motivasi kerja akan lebih berhasil apabila disertai oleh perhatian terhadap kepentingan terintegrasi, yaitu seimbang antara kepentingan organisasi, pimpinan, dan anggota dalam lembaga yang bersangkutan.

\section{Daftar Pustaka}

Adnan, Asmadi. 2007. Studi Penyusunan Indikator Kinerja Pelayanan Pertanahan, BPN RI.

Al Rasyid, Harun. 1994. Statistik Sosial, PPS IV. - 1994. Analisis Jalur sebagai Sarana Statistik dalam Analisis Kausal, Bandung: LP3S, Fakultas Ekonomi IV.

Cafezio, Peter Debra Morehouse. 1998. Secret of Break Through Leadership, Mumbai, Jaico: Publishing House.

Cangara Hafied. 2002. Pengantar Ilmu- Ilmu Komunikasi. Jakarta: PT. Raja Grafindo Persada.

Donnely, James H. 1989. Fundamental of Management/ James H Donnely, Jr., James L. Gibson, John M Ivancevich. $-9^{\text {th }}$ ed.

Gellerman, Saul W. 1983. Motivasi \& Productivitas (terjemahan: Soepomo.S Wardoyo). Jakarta: LPPM.

Gito Sudarmo, Indriyo. 1986.Prinsip Dasar Manajemen. Yogyakarta: BPFE.
Gode, Alexander. 1996. "What is Communication? Journal of communicational.

Jerald Greenberg, Robert A Baron. 1993. Behavior In Organization, Understanding And Managing The Human Side of Work, Fifth Edition, Prentice Hall International Edition.

Hersey and Blanchard. 1993. Management of Organizational Behavio, Publizing Human Resources: Third Edition. New York: Prentice Hall Inc.

James L. and Lois R. Wise. 1999. Public Administration Review.

Lasswell Harold D. 1991. The Analisys of Political Behaviour. New York: University Press.

Lawrence, Kincaid D. dan Wilbur Schramm. 1971. Asas-Asas Komunikasi Antarmanusia. Terjemahan Agus Setiadi. Jakarta: LP3ES.

Liliweri, Alo. 1997. Sosiologi Organisasi. Bandung: Penerbit PT. Citra Aditya Bakti.

Littlejohn, Stephen W. 2002. Theories of Human Communication. Seventh Edition. USA: Wadsworth Publishing Company.

Mangkunegara, A.A. Anwar Prabu. 2006. Evaluasi Kinerja SDM. Bandung: Refika Aditama.

Mc Gregor, D.M. 1961. The Human Side of Interprise, Alih Bahasa B. Uno). New York: Mc Graw Hill.

Nawawi Hadari, Martini. H. 1994. Ilmu Administrasi, Ghalia Indonesia.

Ndraha, Taliziduhu. 1997. Budaya Organisasi. Jakarta: PT. Rineka Cipta.

1997. Metodologi Ilmu Pemerintahan. Jakarta: PT. Rineka Cipta.

2004. Pemberdayaan Masyarakat Dilihat dari Perspektif Kybernology. Jakarta: Unpad, IIP.

-. 2005a. Kybernology: Beberapa Kontruksi Utama, Banten, Sirao Credentia Center. 
2005b. Kybernology: Sebuah Rekonstruksi Ilmu Pemerintahan. Jakarta: PT. Rineka Cipta.

2007. Kybernology sebuah Charta Pembaharuan. Penerbit Sirao Credentia Center.

2007. Kybernology Scientific Movement. Penerbit Sirao Credentia Center.

Parasurahman, A. Valrie, Zeithaml and Leonard L. Berry. 1992. A. Conceptual Model of Service: Quality and Its Implementation for Future Research. Jakarta: Jurnal Marketing.

Rasyid, Ryas. 1997. Makna Pemerintahan: Tinjauan dari segi Etika dan Kepemimpinan. Jakarta: PT. Mutiara Sumber Widya.

Ruben D Brent dan Stewart P Lea. 1998. Communication and Human Behaviour. USA: Pearson.

___ 2006. Communication \& Human Behaviour. USA: Pearson.

Senjaya, Sasa Djuarsa. 1993. Pengantar Komunikasi. Jakarta: Universitas Terbuka.

___-. 1994. Dasar-dasar Perpektif Komunikasi. Program Pascasarjana. Jakarta: Universitas Indonesia.

Sarah Trenholm \& Arthur Jensen. 1996. Communication \& Publication.

Schramm, W. 1980. "The Beginning of Communication study in the united states" dalam communication Year book 4.

Sharif dan Kawan-kawan. 1981. Personil Manajemen dalam Pemerintahan. Jakarta: Gramedia.
Steers, Richard, M. 1985. Efektivitas Organisasi. Jakarta: Erlangga.

Sutermeister, Robert A. 1976. People and Productivity: Third Edition. New York: McGraw Hill Book Company.

Tjokroamidjoyo, Bintoro. 1988. Pengawasan Melekat sebagai Fungsi Manajemen, Jakarta, Makalah disampaikan pada Penataran Pengawasan Melekat bagi Pejabat Pemerintah R.I.

1989. Perencanaan Pembangunan. Jakarta: Gunung Agung.

Wiyono, Djoko. 1999. Manajemen Kepemimpinan dan Organisasi Kesehatan. Surabaya: Airlangga University Press.

\section{Disertasi}

Erika Revida. 2005. "Pengaruh Pemberdayaan Aparatur Birokrasi terhadap Motivasi Kerja dalam Rangka Meningkatkan Kualitas Pelayanan Izin Usaha Industri di Kota Medan Sumatera Utara," Disertasi. Bandung, PPS Unpad.

Hasim. 2008. Pengaruh Perilaku Kepemimpinan dan Budaya Organisasi terhadap Kualitas Pelayanan Persampahan (Studi di Wilayah Kotamadya Jakarta Pusat dan Jakarta Timur), Disertasi, Bandung, PPS Unpad.

Megawati. 2008. Pengaruh Komunikasi Pemerintahan terhadap Partisipasi Masyarakat dalam Pembangunan (Studi Komunikasi Pemerintahan dalam Pelaksanaan Program Pemberdayaan Masyarakat Kelurahan di Kodya Jakarta Selatan), Disertasi, Bandung, PPS Unpad. 